\title{
Isaac Butt: a Singular Political Path
}

Isaac Butt: une trajectoire singulière

\section{Anne-Catherine de Bouvier}

\section{OpenEdition}

\section{Journals}

Electronic version

URL: http://journals.openedition.org/rfcb/3684

DOI: $10.4000 /$ rfcb.3684

ISSN: 2429-4373

\section{Publisher}

CRECIB - Centre de recherche et d'études en civilisation britannique

\section{Electronic reference}

Anne-Catherine de Bouvier, «Isaac Butt: a Singular Political Path », Revue Française de Civilisation Britannique [Online], XXIV-2 | 2019, Online since 19 June 2019, connection on 09 July 2019. URL: http://journals.openedition.org/rfcb/3684; DOI : 10.4000/rfcb.3684

This text was automatically generated on 9 July 2019.

Revue française de civilisation britannique est mis à disposition selon les termes de la licence Creative Commons Attribution - Pas d'Utilisation Commerciale - Pas de Modification 4.0 International. 


\title{
Isaac Butt: a Singular Political Path
}

\author{
Isaac Butt: une trajectoire singulière
}

Anne-Catherine de Bouvier

\section{Introduction}

1 Cet article se propose d'aborder Isaac Butt au prisme de la notion de trajectoire, afin de rendre compte d'une évolution politique qui peut à première vue sembler paradoxale, si l'on adopte la lecture - actuellement remise en cause - qui envisage le parcours de Butt comme celui d'un unioniste fervent devenu nationaliste et fondateur d'un mouvement en faveur du Home Rule. L'historien Colin Reid refuse de voir en Butt, comme cela a souvent été le cas, une simple anticipation du nationalisme plus bouillonnant d'un Charles Stewart Parnell, d'un John Redmond ou d'un John Dillon, ${ }^{1}$ et il s'inscrit en faux contre la lecture inspirée de la biographie de Butt publiée en $1946 .{ }^{2}$ Aux analyses de David Thornley et Lawrence McCaffrey, qui font de Butt un nationaliste, ${ }^{3}$ il préfère le concept d'unionisme constructif, qu'il emprunte à J.W. Good et à son ouvrage de 1920 au titre explicite, Irish Unionism. ${ }^{4}$ En 1843, Isaac Butt, avocat, tory, s'était fait connaître dans la vie politique irlandaise lors d'un débat sur l'abrogation de l'Union, qui s'était tenu à la Corporation de Dublin, ${ }^{5}$ où il siégeait depuis 1840 . L'initiative de ce débat revenait à Daniel O'Connell, champion de l'Émancipation catholique, ${ }^{6}$ whig, député aux Communes depuis 1829, et également membre de la Corporation de Dublin. Depuis 1840, celui-ci promouvait la cause de l'abrogation de l'Union avec l'énergie qu'il avait déployée lors de la campagne pour l'Émancipation catholique. C'est en partisan de l'Union qu'Isaac Butt avait affronté ce formidable tribun.

2 Quelques années plus tard, pendant la Grande Famine, Butt avait déploré le traitement que les autorités britanniques avaient réservé aux souffrances de la population - la méfiance et la parcimonie avec lesquelles l'assistance était distribuée, avant son arrêt pur et simple. En 1848, il avait défendu les nationalistes irlandais qui avaient soutenu par la plume ou participé par l'épée à l'insurrection ratée du mois d'août. En 1867, ce fut également Butt qui assura la défense d'un autre groupe d'insurgés. Une année plus tôt, par la publication de Land Tenure in Ireland: a Plea for the Celtic Race, il s'était nettement 
placé en défenseur des intérêts des tenanciers irlandais. En 1870, il fonda la Home Government Association, et traça les contours d'un futur Home Rule dans un cadre impérial dans Irish Federalism! its Meaning, its Objects and its Hopes. Cet ouvrage plaça la question du Home Rule au centre du débat politique, par-delà le seul cadre irlandais. Trois ans après, en novembre 1873, il prit les rênes du mouvement par le biais de la Home Rule League, créée en remplacement de la Home Government Association; les députés nouvellement élus et issus de cette formation quelques mois plus tard se constituèrent en un groupe parlementaire ${ }^{7}$ qui se proclama indépendant.

Dans son acception physique, la trajectoire se définit comme une courbe, décrite dans l'air ou dans l'espace par un point en mouvement. Elle implique une force, une direction, ainsi qu'une cohérence, d'où son emploi métaphorique pour désigner l'ensemble de la carrière d'une personnalité, même quand il s'agit non pas d'une courbe mais d'une ligne brisée. La trajectoire de Butt apparaît singulière, a fortiori si l'on oppose unionisme et nationalisme de façon rigide. Cette trajectoire singulière nous invite à mettre en œuvre ce qui est sans doute une méta-problématique de civilisation, et à réfléchir en termes de ruptures et de continuité. Faut-il voir dans l'évolution de Butt une rupture, voire une conversion à une cause nationaliste? Ou doit-on plutôt y rechercher des éléments de continuité, à une époque où, comme le note Colin Reid, certaines divisions politiques n'étaient pas encore posées de manière rigide et infranchissable? Cet article penche clairement pour la deuxième interprétation, et s'attachera à mettre en évidence les continuités dans la pensée politique de Butt.

4 On s'intéressera ici à l'évolution politique d'un conservateur que l'on pourrait qualifier d'unioniste malgré tout, ou d'unioniste déçu, pour reprendre l'expression de Ghislaine Saison. ${ }^{8}$ On envisagera la publication de son ouvrage Irish Federalism... (1870) dans une perspective dynamique, en considérant que cette œuvre marqua l'aboutissement de cette évolution politique personnelle, et jeta les bases d'un projet collectif. On abordera enfin la destinée hyperbolique qu'il y esquissa pour la nation - car pour Butt, il existait bel et bien une trajectoire propre à l'Irlande, une trajectoire irlandaise, singulière au sein du Royaume-Uni.

\section{Un unioniste malgré tout}

Par sa naissance, sa formation et le début de sa carrière, Isaac Butt était typique de l' Ascendancy anglo-irlandaise, cette classe à qui l'anglicanisme et la propriété foncière avaient assuré un monopole du pouvoir politique et social tout au long du dix-huitième siècle, et qui conserva bien au-delà son hégémonie sociale et culturelle. Né d'un père dignitaire de l'Église d'Irlande, Isaac Butt fit ses études supérieures à Trinity College, Dublin, le creuset de cette Ascendancy, et y obtint la chaire Whately d'économie politique en 1836. En 1838, il entra au Barreau irlandais, et en 1840, il fut élu membre (alderman) de la Corporation de Dublin, institution qui fut longtemps un bastion conservateur, voire orangiste.

Butt fut très tôt un tory puis un conservateur convaincu, et le demeura toute sa vie. Et par certains aspects, son évolution politique refléta ou accompagna celle de son parti. Il en va ainsi, par exemple, de la question du peuple et du droit de vote. Le Dublin University Magazine avait été co-fondé par Isaac Butt au lendemain de la Réforme électorale de 1832, qui avait élargi le droit de vote, ce que les Conservateurs voyaient comme une menace 
pour la permanence des institutions. Le tout premier article de ce mensuel, en janvier 1833, avait ironisé sur l'attitude du roi et de la noblesse à cette occasion, accusés de céder à l'ochlocratie, et brandissant la perspective d'un retour du jacobinisme, sauf à mettre le pays à l'abri grâce à un retour à la philosophie politique d'Edmund Burke. ${ }^{9}$

En 1874, lors de son premier discours au Parlement en tant que chef de la Home Rule League, Butt soumit à l'approbation des députés Parlement une proposition d'amendement au discours du Trône relatif à la situation irlandaise. ${ }^{10}$ Une partie de son argumentaire était fondée sur le moindre nombre d'électeurs pour les élections législatives, rapporté à la population : dans les comtés, un homme sur huit avait le droit de vote en Angleterre, contre un sur vingt en Irlande ; et on dénombrait en Angleterre 1,2 millions d'électeurs dans les bourgs parlementaires, pour 26 millions d'habitants, contre 50000 électeurs pour 5,5 millions d'habitants en Irlande. Et Butt de demander à la Chambre si le peuple irlandais "had the full benefit of the constitution which had been established in England. $»^{11}$ Mais cet engouement pour le suffrage populaire relève également d'une évolution des conservateurs : arc-boutés contre la Réforme électorale de 1832, puis contre celle proposée par les libéraux en 1866, ils avaient eux-mêmes préparé et voté une mesure d'extension du droit de vote bien plus significative l'année suivante, en $1867 .{ }^{12} \mathrm{Au}$ début des années 1870 , le conservatisme était en train d'évoluer vers ce que l'on appelle le one-nation Conservatism, ou encore Tory democracy, une approche que l'on pourrait, certes de manière anachronique, qualifier de plus inclusive. Les propos de Butt ne relevaient pas d'une conversion singulière, et le terme «popular vote» qu'il employa n'est en rien ironique ni dépréciatif.

Sur ce point, et alors même que Butt prononçait un discours où il réclamait qu'une attention particulière soit portée à la question irlandaise, priant le gouvernement de faire cesser les causes (légitimes) de mécontentement, c'était bien une approche fondamentalement unioniste qui s'énonçait. Butt déplorait l'écart croissant entre l'Angleterre et l'Irlande du point de vue de la loi électorale, écart qui n'était pas un point isolé, mais relevait d'une sorte de mise en quarantaine du pays par l'Angleterre dans son mode de gouvernance: «In fact, the whole system of government in Ireland was based upon distrust of the people, just as the whole system of government in England was based upon trust of the people. $»^{13} \mathrm{~A}$ ce stade, pour Butt, il n'était pas encore question de demander le Home Rule, repoussé à une échéance indéterminée : «He did not at present ask the House to concede Home Rule to Ireland. That question remained to be discussed, and perhaps to be discussed for many years. » Le Home Rule apparaît presque ici davantage comme un horizon, si ce n'est une menace, que comme un projet de plein droit.

Butt demeurait là sur l'argumentaire qui avait été le sien au moment de la Famine : en Irlande, le rejet des institutions impériales, mais surtout anglaises, s'expliquait par un traitement inégal du pays. En 1874, Butt fustigeait les tracasseries policières dont la population était victime. En 1847, il avait dénoncé la justification de la fin de l'assistance publique :

What can be more absurd, what can be more wicked than for men professing attachment to an imperial constitution, to answer claims for state assistance to the unprecedented necessities of Ireland, by talking of Ireland being a drain upon the English treasury? [...] If Cornwall had been visited with the scenes that have desolated Cork, would similar arguments have been used? Would men have stood up and denied that Cornwall was entitled to have the whole country share this extraordinary loss? ${ }^{14}$ 
Dans ce même article, Butt avait évoqué les richesses de l'empire qui, dûment mobilisées, auraient attaché l'Irlande à la Grande-Bretagne plus efficacement que n'importe quelle démonstration de force - une opportunité gâchée.

11 Le discours de 1874 constitua en quelque sorte l'acte de naissance du parti du Home Rule en tant que groupe parlementaire :

For the first time since the Act of Union a majority-he would call it a decisive majority-of Irish Members had been returned pledged to seek such a modification of the arrangements of the Union as would give to Irishmen in Ireland the right of managing their own affairs. He referred to this fact as evidence of dissatisfaction with the existing state of things. The Irish Members who had been returned as Home Rulers were a decisive majority of the Irish representatives, and these had not been pledged to any mere vague declaration in favour of Home Rule. Those who had thought it right to endeavour to excite the attention of the country to the question of Home Rule had deliberately prepared and put before the country the plan contained in the Resolution, which he ventured to say was framed in terms as clear and distinct as possible. ${ }^{15}$

12 A certains égards, cette citation paraît moins décrire une réalité politique que relever d'une volonté performative. La majorité était certes incontestable à la sortie des urnes, avec 59 Home Rulers déclarés sur 105 députés irlandais à Westminster. Mais une fois au Parlement, cette majorité avait fondu, et il ne s'était plus trouvé que 46 élus pour s'inscrire véritablement dans ce futur groupe parlementaire. On rappellera enfin que Butt avait finalement renoncé à exiger de ces parlementaires un engagement formel (pledge). Toutefois, malgré ces incertitudes, le langage est, à plusieurs reprises, celui de la rupture. Il s'agit d'une rupture temporelle: la citation ci-dessus fait référence à un événement sans précédent depuis l'Union. La rupture est également politique, car la création de ce groupe parlementaire nouveau est présentée comme elle-même créatrice d'un nouvel ordre. Repousser un débat sur le Home Rule à un horizon plus lointain, et flou, était peutêtre une manière de chercher à amortir l'effet de cette nouveauté.

Mais le langage demeure celui de l'unité. Au début du discours, Butt affirmait que le projet de Home Rule n'entamerait en rien les prérogatives de la couronne, ni la stabilité de l'empire, et convoquait à l'appui de cette affirmation les précédents canadien et australien. Vers la fin, les protestations d'unité se font à nouveau entendre: avant d'évoquer le Home Rule en tant que projet concret et non en tant qu'horizon plus flou et plus lointain, ses partisans devaient, selon Butt, convaincre qu'ils ne voulaient pas de séparation. Le cadre géopolitique devait demeurer celui de l'empire, et le cadre institutionnel, celui de la constitution britannique. Et c'est précisément son maintien que permettrait le Home Rule :

That question remained to be discussed, and perhaps to be discussed for many years. But first the advocates of Home Rule must satisfy the English people that they were not seeking separation. Ireland had given up the idea of separation, because she had before her the prospect of obtaining another and a far better thing. He did not believe Ireland would ever be content with the existing state of things; but if Englishmen approached the subject with unprejudiced minds there would be no difficulty in framing a measure which would make Ireland contented, while the integrity of the Empire would be perfectly maintained..$^{16}$

Le Home Rule au chevet de l'unité : cette position a certes parfois tenu d'un équilibre impossible. 


\section{L'Union, la nation et l'empire : une trajectoire collective}

15 seuil, héraut de Parnell, ou comme un « unioniste inventif » selon l'expression de C. Reid, ${ }^{17}$ sa singularité tient également dans son rapport à l'histoire. Par certains aspects, il se situe pleinement dans la lignée de la Jeune Irlande, et peut-être par-delà, dans la tradition antiquaire de la fin du XVIII ${ }^{\mathrm{e}}$ siècle. ${ }^{18}$ Irish Federalism comporte des références explicites à certains des topoï de ce premier nationalisme culturel, et notamment la référence à l'Ile des Saints et des érudits, ou encore au Voyage de Saint Brendan. ${ }^{19}$

En revanche, Butt diffère sur l'histoire plus récente, et en particulier sur le Parlement de 1782, également appelé Parlement de Grattan. En 1782, les membres de la Chambre des communes d'Irlande avaient voté unanimement une déclaration d'indépendance législative : toute loi votée à Londres, et affectant l'Irlande, devrait être approuvée par le Parlement de Dublin pour pouvoir s'appliquer. Dans l'histoire nationaliste qui s'écrivit au dix-neuvième siècle, cet épisode constituait un véritable âge d'or - un deuxième âge d'or, après le haut Moyen Âge - et venait étayer les arguments en faveur de l'abrogation de l'Union et de la séparation. N'était-ce pas ce parlement qui avait mis un terme aux Lois Pénales? créé les conditions d'un début de décollage économique?

Ce n'est pas le bilan qu'en tirait Butt, du moins pas le seul bilan. Son point de critique principal portait sur la relation entre l'Irlande, l'Angleterre et l'empire telle qu'elle existait dans ce mode institutionnel :

Thus stood the Irish Parliament in constitutional position from 1782 until its dissolution. It had full and entire control over everything Irish, where it belonged to Parliament to control. The Irish House of Commons were absolute masters of Irish taxation. Not a penny could be raised from Ireland without their consent; but, on the other hand, in all the external affairs of the Empire, Ireland had no voice. The King of England declared war and made peace by proclamations framed in his English Privy Council, and by its advice. Treaties with foreign powers were made by English ministers, and could only require the sanction of the Irish Parliament if they contained stipulations which might affect Irish trade. Over India and the Colonies, the English Parliament exercised supreme and exclusive control. All those which we now term Imperial affairs were entirely under the direction of the English Ministry and Parliament. ${ }^{20}$

En d'autres termes, au regard de l'empire, l'Irlande n'existait pas. Dans la logique impériale de Butt, cela amputait considérablement la portée et la valeur de cette indépendance; tandis que l'Irlande d'avant l'Union n'était qu'un satellite de l'Angleterre, la solution fédérale la placerait au cœur de l'empire.

La logique de Butt n'était pas séparatiste, loin s'en faut, il considérait la dynamique séparatiste comme indissociable du sectarisme confessionnel et de ses vieux fléaux. Lors du débat de 1843 précédemment évoqué, l'argument où il semble avoir mis le plus de passion fut celui selon lequel un débat plus effectif sur l'abrogation de Union prendrait inévitablement une coloration sectaire, et livrerait le pays à ses vieux démons. Selon lui, croire que l'on pouvait chercher à mettre en œuvre une séparation des deux îles sur un plan purement politique et technique, sans convoquer le religieux, était illusoire. Butt convoqua la mémoire des années 1790 et des Irlandais Unis :

so thought the men who in 1790 began to attempt to separate Ireland from England. Did [the audience] believe it possible that a question of this kind, a question 
involving the natural relations between England and Ireland could be agitated without calling into action the elements of religious discord? Never was hope more vain. [...] The Protestant would be halloed against the Catholic, and the Catholic against the Protestant, by every bad recollection that malicious ingenuity could rake up from the history of other times. ${ }^{21}$

Et Butt d'inviter à ne pas réveiller les démons de l'histoire :

No, let the memory of past wrongs be forgotten, away with the evil spirit that would wander among the tombs, to hold communion only with the evil things of other days, and by an infernal necromancy call from the grave the hideous spectres of forgotten crimes to disturb the present generation with the guilt and the passions of the past. ${ }^{22}$

$21 \mathrm{Si}$, dans ce début des années 1840, les membres de la Jeune Irlande avaient cherché dans l'Histoire un moyen d'action sur les hommes, Butt s'en méfiait, et continua de s'en méfier. D'où sans doute cette difficulté qui persiste pour le placer sur des lignes politiques cristallisées autour d'histoires et de mémoires opposées, violentes, et souvent brandies en étendard. Et d'où peut-être aussi la moindre postérité d'une proposition au conservatisme assumé, à la dimension technique parfois sèche, et aux envolées de sentiment national qui peuvent sembler désincarnées.

Face au constat d'échec de l'Union, l'auteur d'Irish Federalism n'en demandait toujours pas l'abrogation en 1870, au sens où le terme de Repeal était entendu : un retour à la situation constitutionnelle qui l'avait immédiatement précédée. Butt n'idéalisait pas le Parlement de Grattan, pas davantage en 1870 qu'en 1843. C'était autre chose qu'il espérait voir advenir. Le fédéralisme qu'il appelait de ses vœux était de nature à renforcer les liens plus qu'à les distendre, a fortiori qu'à les rompre. Au retour sur le passé, Butt préférait la projection dans une destinée à accomplir dans un avenir non défini. Inscrire le projet dans le double espace des Iles Britanniques et de l'empire fermait la porte, du moins en théorie, au remplacement de l'argument par le ressassement mémoriel.

\section{Une destinée manifeste pour l'Irlande?}

Si la pleine inclusion de l'Irlande dans un espace britannique et impérial devait lui permettre de sortir des cycles de violence qui avaient marqué son histoire, il y avait une réciproque. L'inclusion, et non plus la domination de l'Irlande était de nature à apporter une protection, à l'Angleterre et à l'empire. Butt, sans doute influencé en cela par les théories d'un âge d'or irlandais, et par la vision d'une Irlande qui aurait servi de sanctuaire aux productions des cultures chrétienne et gréco-romaine lors des invasions barbares, y voyait une réserve de spiritualité. ${ }^{23}$

A une époque plus récente, et de manière nettement plus pragmatique, il avait semblé nécessaire d'arrimer l'Irlande à l'Angleterre, pour que la vulnérabilité et la volatilité politique de la première ne fût pas une source de faiblesse pour la seconde, dans le contexte des guerres révolutionnaires - c'était la logique qui avait présidé à l'Union. Pour Butt, en 1870, le danger était de retour : l'Union avait échoué, tandis que les menaces extérieures renaissaient. ${ }^{24}$ Il convient donc de ne pas considérer ce demi-avertissement que l'on trouve dès la préface comme une simple coquille rhétorique vide :

I have long since had the conviction forced upon me that it is equally essential to the safety of England and to the happiness and tranquillity of Ireland, that the right of self-government should be restored to this country. ${ }^{25}$ 
menaces s'y font plus précises :

The Union was carried into effect to consolidate the power of the Empire when England was engaged in the great effort of the revolutionary war. In the events which now threaten the peace of Europe, and of the world, it is only by a revision of that Union that the same end can be attained. It is, after all, in periods of great national emergencies that the minds of men are roused to achieve great results. It was amid the troubles and perplexities which followed the campaign of Sadowa, that Austrian statesmen rose to the necessity of giving to Hungary the free constitution which has made that country the strength, instead of the weakness, of the Austrian Confederation. English statesmen would do well to profit by the lesson before a war overtakes them, with Ireland still the weakness of the British state. ${ }^{26}$

Une Irlande apaisée, et restaurée dans sa dignité par l'arrangement fédéral proposé serait non seulement un poids de moins face à une menace extérieure, mais également un recours contre une menace intérieure. Et cette menace était identifiée : il s'agissait de la montée en puissance des masses, potentiellement révolutionnaires. Répondant à l'objection selon laquelle un parlement indépendant en Irlande pourrait être tenté par un renversement de l'ordre établi, Butt avança au contraire que

[...] these imaginations of democratic violence from an Irish House of Commons are visionary in the extreme. There is no people on earth less disposed to democracy than the Irish. The real danger of democratic or revolutionary violence is far more with the English people. The time may not be far distant when a separate Irish Parliament might be, in the best sense of the word, the Conservative element in the British Confederation. ${ }^{27}$

L'Irlande aurait ainsi constitué, selon Butt, une réserve de conservatisme, étayant la stabilité de l'ensemble. Enfin, l'Irlande pouvait devenir tant un exemple qu'une réserve de piété :

Above all, we have not a population outgrowing the means of religious instruction, and living in a state of heathenism. It would be utterly impossible in Ireland for incidents to occur like those which we are assured by parliamentary papers to be common "in the black country," where grown up men and women knew nothing of Jesus Christ. In England there are many publications advocating infidel opinions, and enjoying a large circulation - in Ireland there is not one. Ireland is essentially a religious country, and men of all creeds shrink from the scepticism which is spreading rapidly through English society. I say it in deep sorrow, wealth and luxury have brought to all classes in England contaminations and abominations from which Ireland may rejoice that her poverty has kept her free..$^{28}$

Les éléments qui sous-tendent habituellement la critique de l'Irlande sont repris, et renversés pour devenir des vertus : la pauvreté devient humilité et frugalité chrétiennes, la religion n'est plus un élément de division, mais de cohésion sociale. Si l'utilité immédiate de cette réserve spirituelle n'était pas clairement définie, les accents de Butt étaient incontestablement providentialistes, et la destinée de l'Irlande, presque manifeste :

if ever the time comes when the evil influences which unhappily exist in England should prevail in her social and political system over the virtues which unquestionably belong to a large portion of her people, it would be well for England herself that she had near her, and allied to her, a legislature and a nation which those corrupting influences had never reached. ${ }^{29}$

L'Irlande pourrait être l'instrument de la rédemption de l'Angleterre. 
30 Le chapitre IX de l'ouvrage, dont le nationalisme inspiré contraste parfois de manière saisissante avec le pragmatisme constitutionnel de chapitres antérieurs, ${ }^{30}$ plus techniques, s'intitule précisément «The Destiny of Ireland.» Butt y insistait sur ce dont l'Irlande avait réchappé : guerres, massacres et famines. Il y voyait la preuve d'une destinée spéciale de la nation irlandaise, même si elle n'était pas encore pleinement révélée, et demeurait dans un horizon encore mystérieux. ${ }^{31}$ Elle attendait son heure :

I do not believe that it is without a purpose that the God of nations has thus preserved and multiplied the Irish race - that their nationality has thus been kept separate and distinct. [...] The Providence that bestowed upon Ireland these great qualities must surely intend that one day or other they would find their work to do. 32

Dans cette logique, l'échec même de l'assimilation de l'Irlande au reste du Royaume-Uni devenait un signe d'élection. De même, un peu plus haut, Butt avait vu dans la nonassimilation religieuse de l'Irlande un signe, sinon d'élection, du moins d'exception. Si, selon Butt, on trouve partout abondance de héros et de martyrs, des figures singulières de résistance, "history records nothing like the fidelity with which in Ireland a whole people adhered to their religious beliefs. ${ }^{33}$ Il existait donc une singularite irlandaise, puissante, irréductible, qui selon lui ne pouvait que découler d'un dessein divin.

L'Irlande figure, dans la représentation des peuples selon Butt, comme une terre d'élection, ce qu'il suggéra à plusieurs reprises par les références au peuple élu, le peuple juif. L'analogie n'était pas nouvelle : l'hebdomadaire nationaliste The Nation, par exemple, avait établi à plusieurs reprises une analogie entre les Irlandais et les Hébreux réduits en esclavage, par Pharaon représentant le pouvoir anglais. L'oppression du peuple juif réduit en esclavage, la fuite d'Egypte, la vaine poursuite lancée par Pharaon et la punition de ses armées et de sa terre constituent un épisode biblique tout indiqué pour sous-tendre un argumentaire nationaliste. Un peuple a été réduit en esclavage, mais ses efforts pour secouer son joug sont inspirés, approuvés et facilités par la puissance divine. On ne peut dès lors plus parler de rébellion, condamnable, mais de refus, et de marche vers un destin supérieur et singulier. Ce n'est pas tant la fuite d'Egypte qui retint l'attention de Butt, que l'actualité de ce destin : celui d'un peuple qui avait survécu aux persécutions, aux famines et aux destructions de toutes sortes, et a essaimé de par le monde. Irish Federalism ... avait déjà très largement intégré l'existence d'une diaspora irlandaise.

Butt fit toutefois un peu plus que reprendre l'analogie, et alla jusqu'à suggérer une identité originelle, en vertu d'une légende récurrente, qui voit dans les Celtes les descendants de l'une des dix tribus perdues d'Israel. Si Butt se gardait de cautionner sans réserve cette thèse, qu'il associait encore au légendaire, il lui accorda toutefois une part de véracité :

There is no people on earth about whose origin so many strange traditions gather, as those which surround the cradle of the Irish race. The strangest of all is that which associates them with the Jewish exodus from Egypt, and traces back the wanderings of the first settlers in Ireland to the shores of the Red Sea. These stories are not altogether mythical. Like most historical traditions of the olden time, legend mingles fable with the truth. ${ }^{34}$

Cette hypothèse permet, une fois encore, de renverser un stéréotype négatif pour le transformer en attribut supérieur: les Celtes d'Irlande ne seraient ainsi pas un peuple irrémédiablement barbare et inférieur aux Anglo-Saxons, mais les descendants en ligne directe du peuple élu. ${ }^{35}$ 


\section{Conclusion} d'Isaac Butt, le discours qu'il tint en faveur de l'Union le 28 février 1843, est à la fois pertinent et éclairant dans le cadre de la perspective abordée ici. Cela permet d'écarter de manière définitive une lecture simpliste, celle d'un unioniste se découvrant nationaliste à la faveur de la Famine, et reniant ses convictions antérieures. Cela permet également de s'affranchir d'une interprétation qui, tenant à un cloisonnement rigide, post-1880, ne verrait dans ce nationalisme, certes peu virulent, que l'opportunisme d'un homme cherchant à sauver sa carrière politique, ou d'une classe cherchant une alternative et une réserve électorale pour contrer les libéraux et leurs réformes.

Commentant le discours de Butt en 1843, Daniel O'Connell avait déclaré :

A man of his genius must have had some yearning for his native land, and though the word Ireland may not yet sound as musically in his ears as in mine, it has in his private ear its charm for him. Depend upon it that Alderman Butt is in his inmost soul an Irishman, and that we will have him struggling with us for Ireland yet. ${ }^{36}$

Certes, pour Daniel O'Connell, cela signifiait concrètement prendre fait et cause pour le Repeal, ce qui n'a pas été vérifié par la trajectoire politique de Butt, qui continua de refuser l'idée de séparation, comme l'idée d'un retour au Parlement de Grattan à laquelle elle était chevillée dans l'esprit des nationalistes constitutionnels tels que O'Connell. Toutefois, cette analyse s'avère totalement pertinente pour ce qui est du sentiment national ; pour reprendre la métaphore contenue dans cette citation, on pourrait dire que la sensibilité privée finit par trouver son expression dans le discours public.

Le nationalisme de Butt ne doit pas être opposé à son conservatisme, ni à son impérialisme. Avec C. Reid, on pourrait plutôt parler d'unionisme inventif. Sa trajectoire (r)établit du lien entre différents épisodes, sinon depuis l'Union, du moins depuis les années 1830 , ainsi que du lien entre des préoccupations sectionnelles et une trajectoire nationale - entre des revendications et un projet. Selon Reid,

Butt provided a crucial bridge which helps to explain the shift from sectional discontent, such as agrarianism and agitation about Fenian prisoners, towards the broader and more nationally oriented principle of Home Rule [...] Taken as a whole, Butt's pamphleteering activities during the 1860 s and 1870 s constituted a sustained critique of the post-Famine Union, from a Conservative perspective: he provided the rationale for Home Rule, and his example offered an illuminating demonstration of the radicalisation of Irish sentiment in favour of self-government. 37

Quant à la critique de l'Union portée par Butt, elle ne portait pas tant sur le principe même - une véritable union des peuples - que sur le résultat obtenu, presque diamétralement opposé, la discorde et l'antagonisme.

The late nineteenth-century dichotomy between unionism and nationalism in Ireland, underpinned by religious and national differences to which the Home Rule debate gave substance, was not as all-consuming in the 1860s and 1870s: political and intellectual space existed for unionists such as Butt to re-imagine the Union in ways which embraced Irish nationalist sentiments. ${ }^{38}$

Il n'est pas tant question de contradiction que de complexité. Il faut ici l'accepter, sans chercher à rabattre Isaac Butt sur des lignes de partage cristallisées ultérieurement. Le projet esquissé par Butt reposait sur deux conditions: un éveil de la classe politique 
britannique à la nécessité d'un changement institutionnel profond, se manifestant par un accueil bienveillant de la demande de Home government, et l'union de (presque) tous les Irlandais dans cette démarche. Elle ne se sont pas réalisées.

\section{BIBLIOGRAPHY}

\section{Sources primaires}

Butt, Isaac, Land tenure in Ireland : a Plea for the Celtic Race (Dublin, J. Falconer, 1866).

Butt, Isaac, Ireland's Appeal for Amnesty: A Letter to the Right Honourable W.E. Gladstone, MP (Londres et Glasgow, 1867).

Butt, Isaac, Home Government for Ireland: Irish Federalism ! Its Meanings, its Objects, and its Hopes [1870], $3^{\text {ème }}$ édition (Dublin, 1871).

Dublin University Magazine, janvier 1833.

Dublin University Magazine, avril 1847.

A Full and Revised Report of the Three Days' Discussion in the Dublin Corporation on the Repeal of the Union, édité par John Levy (Dublin, James Duffy, 1843). Merci à L. Colantonio pour ce document. Hansard, House of Commons Debates, vol. 218, 20 March 1874,

\section{Sources secondaires}

Bull, Ph. «Isaac Butt and the Politics of Accomodation », Australian Journal of Irish Studies, 1 (2001), pp. 158-66.

Comerford, R. V. «Isaac Butt and the Home Rule Party, 1870-77 », in W. E. Vaughan (ed.), A New History of Ireland VI: Ireland Under the Union, vol. 2, 1870-1921 (Oxford, Clarendon Press, 1996), pp. $1-25$.

Golden, J. J., « The Protestant Influence on the Origins of Irish Home Rule, 1861-1871 », English Historical Review, Vol. CXXVIII (2013), pp. 1483-516.

Hoppen, K. Theodore, Elections, Politics, and Society in Ireland, 1832-1885 (Oxford, Clarendon Press, 1984).

Jackson, Alvin, Home Rule: An Irish History, 1800-2000 (Londres, Weidenfeld and Nicolson, 2003). Jackson, Alvin, The Two Unions: Ireland, Scotland and the Survival of the United Kingdom, 1707-2007 (Oxford, Oxford University Press, 2012).

McCaffrey, Lawrence. J. «Isaac Butt and the Home Rule Movement: A Study in Conservative Nationalism », Review of Politics, 22 (Janvier 1960), pp. 72-95.

McCaffrey, Lawrence. J., « Irish Federalism in the 1870s: A Study in Conservative Nattionalism », Transactions of the American Philosophical Society, lii (1962), pp. 1-58. O’Day, Alan. “Defining 
Ireland's Place in Parliament Institutions: Isaac Butt and Parnell in the 1870s" in A. O'Day (ed.), Government and Institutions in the post-1832 United Kingdom, Lewiston, NY : The Edwin Mellen Press, 1995.

Reid, Colin, « 'An experiment in Constructive Unionism' : Isaac Butt, Home Rule and Federalist Political Thought during the 1870s », English Historical Review Vol. CXXIX (2014), pp. 332-361.

Saison, Ghislaine, «Isaac Butt : itinéraire d'un unioniste déçu » in Penseurs conservateurs au Royaume-Uni - De Burke au thatchérisme, Maurice Chrétien (dir.) (Lyon, Presses Universitaires de Lyon, 2008, pp. 126-151.

Spence, Joseph, « Isaac Butt, Irish Nationality and the Conditional Defence of the Union, 1833-70 » in George Boyce et Alan O'Day (dirs.), Defenders of the Union. A Survey of British and Irish Unionism since 1801 (Londres et New York, Routledge, 2001).

Thornley, David, Isaac Butt and Home Rule (Londres, MacGibbon \& Kee, 1964).

White, T. de Vere, The Road of Excess (Dublin, Browne \& Nolan, 1946).

\section{NOTES}

1. Colin Reid, « 'An experiment in Constructive Unionism' : Isaac Butt, Home Rule and Federalist Political Thought during the 1870s », English Historical Review Vol. CXXIX (2014), p. 333.

2. Terence de Vere White, The Road of Excess (Dublin : Browne \& Nolan, 1946).

3. Lawrence J. McCaffrey, L. J. «Isaac Butt and the Home Rule Movement: A Study in Conservative Nationalism », Review of Politics, 22 (Janvier 1960), 72-95. Lawrence J. McCaffrey, « Irish Federalism in the 1870s: A Study in Conservative Nationalism ", Transactions of the American Philosophical Society, lii (1962), pp. 1-58. David Thornley, Isaac Butt and Home Rule (Londres, MacGibbon \& Kee, 1964).

4. J.W. Good, Irish Unionism, Dublin, 1920.

5. Il s'agit des instances municipales. Le texte des débats, auquel il sera fait référence plus loin, est reproduit dans A Full and Revised Report of the Three Days' Discussion in the Dublin Corporation on the Repeal of the Union, édité par John Levy (Dublin, James Duffy, 1843).

6. Au cours du dix-huitième siècle, les catholiques irlandais s'étaient vu retirer leurs droits civiques, et reléguer au rang de non-citoyens, du fait d'un ensemble de mesures appelées, dans leur ensemble, les lois Pénales. Beaucoup de ces dispositions avaient été abrogées à la fin du siècle, mais certaines subsistaient encore. Ainsi, les termes du serment que devaient prêter les parlementaires à leur prise de fonction interdisaient de facto à un catholique de siéger. En 1829, au terme d'une campagne de mobilisation populaire sans précédent, initiée et animée par Daniel O'Connell à partir de 1823, ces dernières restrictions furent abrogées par ce qu'il est convenu d'appeler l'Acte d'Émancipation catholique.

7. Il faut toutefois prendre ce terme avec prudence, et dans on contexte. La notion de discipline parlementaire était encore en devenir, et dans le cas de la Home Rule League, certains parlementaires semblent s'être davantage fait élire sous cette étiquette par opportunisme que par conviction profonde. Enfin, il faut ici rappeler que la notion de Home Rule était alors susceptible de recouvrir des définitions suffisamment différentes pour rendre problématique la cohésion du groupe. La singularité de Butt tient non seulement à une pensée qu'il n'est pas toujours aisé de classer ou d'étiqueter, mais aussi à un certain isolement. Butt ne fut ni un chef charismatique incontesté, ni un tribun, ni un homme de grands réseaux.

8. Ghislaine Saison, «Isaac Butt : itinéraire d'un unioniste déçu " in Penseurs conservateurs au Royaume-Uni - De Burke au thatchérisme, Maurice Chrétien, dir. (Lyon, Presses Universitaires de Lyon, 2008), pp. 126-151. 
9. Dans ce premier article, en forme de dialogue fictif, le sage Neverout s'adresse en ces termes au fougueux Poplar: "If [the King and the nobility] have stooped, from consciousness of inability to resist the power and violence of the ochlocracy, it is not for such as you to stand erect in the contest. " in "The Present Crisis: a dialogue", The Dublin University Magazine: a Literary and Philosophic Magazine, January 1833. In The Dublin University Magazine ..., vol.i, January to June 1833 (Dublin, William Curry Jr \& Co., 1833), p. 2, https://babel.hathitrust.org/cgi/pt? id=uva.x030236548;view=1up;seq=1, consulté le 28 février 2018.

L'ochlocratie est un terme péjoratif qui désigne un gouvernement désordonné, soumis à la violence et l'intimidation des masses. Il s'agit d'une allusion aux manifestations populaires qui avaient in fine eu raison des oppositions.

10. «We also think it right humbly to represent to Your Majesty that dissatisfaction prevails very extensively in Ireland with the existing system of government in that country, and that complaints are mode that under that system the Irish people do not enjoy the full benefits of the Constitution and of the free principles of the law and we humbly assure Your Majesty that we shall regard it as the duty of Parliament, on the earliest opportunity, to consider the origin of this dissatisfaction with a view to the removal of all just causes of discontent. " (Isaac Butt, speech delivered during the address in answer to the Queen's speech, 20 March 1874, Hansard, House of Commons Debates, vol. 218, c. 111.

11. Ibid., c. 115.

12. Cette réforme fit passer le nombre d'électeurs de 1360000 en 1866 à 2456000 en 1868.

13. Butt, Address in answer to the Queen's speech, c. 116.

14. "The Famine in the Land ", April 1847, The Dublin University Magazine: A Literary and Philosophic Review. The Dublin University Magazine ..., vol. xxix, January to June 1847 (Dublin, James McGlashan, 1847), pp. 514-15.

15. Butt, Address in answer to the Queen's speech,.c. 111.

16. Ibid., c. 117.

17. Colin Reid «'An experiment in Constructive Unionism': Isaac Butt, Home Rule and Federalist Political Thought during the 1870s ", English Historical Review, Vol. CXXIX (2014), p. 336.

18. Voir Ghislaine Saison, «Isaac Butt : itinéraire d'un unioniste déçu » in Penseurs conservateurs au Royaume-Uni - De Burke au thatchérisme, Maurice Chrétien, dir. (Lyon, Presses Universitaires de Lyon, 2008), pp. 126-151.

19. Au début du sixième siècle, saint Brendan, qui a véritablement existé, aurait accompli un très long voyage maritime, relaté dans la Navigatio Brendani (huitième siècle), texte où certains commentateurs ont vu une toute première découverte de l'Amérique.

20. Isaac Butt, Irish Federalism, p. 39.

21. A Full and Revised Report, p. 96.

22. Ibid., p. 99.

23. Nous y reviendrons un peu plus loin.

24. Dans les faits, c'était plus précisément la montée de la Prusse qui inspirait des inquiétudes quant à la paix en Europe.

25. Butt, Irish Federalism, préface à la première édition.

26. Ibid., p. 29. On notera ici que c'est bien à une révision de l'Union qu'appelait Butt, en aucun cas à une abrogation.

27. Ibid., p. 64.

28. Ibid., p. 104.

29. Butt, Irish Federalism, p. 106.

30. Joseph Spence parle des oscillations de Butt, entre « Tory pessimism » et «nationalist idealism »; voir « Isaac Butt, Irish Nationality and the Conditional Defence of the Union, 1833-70 » in George Boyce et Alan O'Day, dirs., Defenders of the Union. A Survey of British and Irish Unionism since 1801 (Londres et New York, Routledge, 2001), p. 84. 
31. Il s'agit très clairement d'une rédemption politique et spirituelle de l'Angleterre, mais peutêtre pas uniquement ; et en tout état de cause, on peine à en imaginer précisément les contours.

32. Butt, Irish Federalism, p. 103.

33. Ibid.

34. Ibid., pp. 97-98.

35. On peut y voir l'expression d'un sentiment national ou une flatterie à l'intention de celui-ci. C'était également un argument tactique : l'Irlande n'était pas une charge, mais une richesse, presque un trésor.

36. A Full and Revised Report, p. 107. Merci à Laurent Colantonio pour ce document, et pour la référence précise de cette citation.

Si, en 1843, O'Connell avait perçu ce que pouvait être la trajectoire de Butt, réfutant en quelque sorte par anticipation l'accusation d'opportunisme, celui-ci tint à réfuter les accusations de sectarisme et de bigoterie portées par les détracteurs du Libérateur :

"Let me say it with melancholy reverence for his memory, Protestant Ireland has never, in this respect, done justice to this great Irishman. No man ever lived more opposed to religious intolerance - no man would more strenuously have opposed any sectarian ascendancy, or any attempt at political dictation by any spiritual power. No misrepresentation of his character could be more unjust than that which would describe him as the slave of prejudice or bigotry, or the servile adherent of ecclesiastical rule." (Butt, Irish Federalism, p. 107)

37. Colin Reid "'An experiment in Constructive Unionism' : Isaac Butt, Home Rule and Federalist Political Thought during the 1870s ", English Historical Review Vol. CXXIX (2014), p. 344.

38. Ibid., p. 336.

\section{ABSTRACTS}

This article aims to try and define more precisely and accurately the political views of Isaac Butt, as they may first seem contradictory: was he a nationalist? A unionist? This issue is made more confusing by the fact that from 1878-80 onwards, British political life became polarised between the supporters of Home Rule allied with the Liberals on the one hand and, on the other hand, the Conservatives and Unionists. What will be shown is that Isaac Butt's evolution politically was not marked by a rupture but by continuity and that his conservatism fed into his nationalism and his imperialism and vice versa.

Cet article se propose d'essayer de cerner plus précisément et plus justement les positions d'Isaac Butt qui, de prime abord, peuvent paraître contradictoires : unioniste et nationaliste. Elément de brouillage supplémentaire, la polarisation politique du débat à partir des années 1878-1880 a aussi fossilisé une alliance entre libéraux et partisans du Home Rule d'une part, et conservateurs et unionistes d'autre part. Nous verrons ici que l'évolution politique de Butt ne relève pas d'une rupture, mais d'une véritable trajectoire, où conservatisme, nationalisme et impérialisme, loin de s'opposer, se nourrissent les uns des autres. 


\section{INDEX}

Mots-clés: Irlande, nationalisme, empire, union(isme), fedération, conservatisme

Keywords: Ireland, nationalism, empire, union(ism), federation, conservatism

\section{AUTHOR}

\section{ANNE-CATHERINE DE BOUVIER}

Anne-Catherine de Bouvier, an alumna of the Ecole Normale Supérieure de Fontenay-St Cloud and agrégée d'anglais, is Associate Professor at the University of Caen, where she teaches Irish and British history, and translation. In 1998, she defended a PhD on Ireland's political elites 1800-1829. Her research focuses on politics and history of ideas in 19th century Ireland and Britain. She has just joined the editorial board of Etudes Irlandaises. She co-edited a special issue of the RFCB on the Great Irish Famine, 1845-1851, in 2014, with Christophe Gillissen; recently, she contributed to La Question du Home Rule en Irlande, 1870-1914 (C. Maignant, ed., Atlande, 2018).

Anne-Catherine de Bouvier, ancienne élève de l'Ecole Normale Supérieure de Fontenay-St Cloud et agrégée d'anglais, est Maître de Conférences à l'Université de Caen, où elle enseigne la civilisation irlandaise et britannique, ainsi que la traduction. En 1998, elle a soutenu une thèse sur les élites politiques en Irlande, 1801-1829. Ses recherches portent sur la politique et l'histoire des idées au XIX ${ }^{\mathrm{e}}$ siècle, en Irlande et en Grande-Bretagne. Elle vient de rejoindre le comité de direction d'Etudes Irlandaises. Elle a co-dirigé, avec Christophe Gillissen, un numéro spécial de la RFCB sur la Grande Famine en Irlande, 1845-1851, et a récemment contribué à La Question du Home Rule en Irlande, 1870-1914 (C. Maignant, dir., Atlande, 2018). 